\title{
Pemanfaatan Botol Plastik Bekas Dan Sampah Plastik Untuk Bahan Konstruksi (Ecobrick) Sebagai Upaya Pengurangan Limbah Plastik
}

\author{
Rahmani Kadarningsih', Indriati Martha Patuti², Aryati Alitu ${ }^{3}$ \\ 1,2,3 Universitas Negeri Gorontalo, Jl. Jend. Sudirman No.6, Dulalowo Tim., Kota \\ Tengah, Kota Gorontalo, Gorontalo 96128, Indonesia \\ email: rkadarningsih@ung.ac.id, indri.m.patuti@ung.ac.id, aryati nining@yahoo.com
}

\begin{abstract}
Abstrak
The consumption of plastic materials is increasing every day so that the consequences are getting worse. Because plastic is a synthetic polymer material so it is difficult to degrade in nature. The results of observations made by the students were then followed by a work program planning meeting to be offered to community members and youth organizations. The meeting resulted in a decision that one of the programs to be implemented was the use of plastic bottles and plastic waste as construction materials for village barriers and trash cans. Ecobrick making takes a long time, therefore it can be done in between spare time so that one day when it has been collected in large quantities it can be used at once. If the time available is short enough, the bottle filling can be replaced with dry sand or gravel. Without being aware using bottles and plastic waste as environmentally friendly bricks is a small step that over time has a huge effect on environmental sustainability.
\end{abstract}

Kata Kunci: trash, plastic, ecobrick

\begin{abstract}
Konsumsi bahan plastik semakin hari semakin banyak sehingga akibat yang ditimbulkan semakin buruk. Karena barang berbahan plastik merupakan bahan polimer sintetis sehingga sulit terdegradasi di alam. Hasil observasi yang dilakukan mahasiswa kemudian dilanjutkan dengan rapat perencanaan program kerja yang akan ditawarkan untuk warga masyarakat dan karang taruna. Rapat tersebut menghasilkan keputusan bahwa program yang akan dilaksanakan salah satunya adalah pemanfaatn botol plastik bekas dan sampah plastik sebagai bahan konstruksi pembatas dusun dan tempat sampah. Pembuatan ecobrick memakan waktu yang cukup lama, oleh karena itu dapat dilakukan disela-sela waktu luang sehingga suatu saat bila sudah terkumpul dalam jumlah banyak bisa digunakan sekaligus. Apabila waktu yang tersedia cukup singkat isian botol dapat digantikan dengan pasir kering ataupun kerikil. Penggunaan botol dan sampah plastik sebagai batu bata ramah lingkungan tanpa disadari merupakan suatu langkah kecil yang lama kelamaan menimbulkan efek yang sangat besar bagi kelestarian lingkungan.
\end{abstract}

Kata Kunci: sampah, plastik, ecobrick

(C) 2021 Rahmani Kadarningsih, Indriati Martha Patuti, Aryati Alitu Under the license CC BY-SA 4.0

Correspondence author: Rahmani Kadarningsih, rkadarningsih@ung.ac.id,

Gorontalo, and Indonesia 


\section{PENDAHULUAN}

Konsumsi bahan plastik semakin hari semakin banyak sehingga akibat yang ditimbulkan semakin buruk. Karena barang berbahan plastik merupakan bahan polimer sintetis sehingga sulit terdegradasi di alam. Perlu waktu yang panjang agar dapat terurai di alam, seperti dijelaskan pada Gambar 1. Belum lagi jika sudah masuk musim penghujan, sampah plastik akan semakin sulit di tangani dan dampaknya akan dirasakan masyarakat seperti datangnya bencana banjir. Masyarakat juga akan terganggu kesehatannya karena bahan plastik mengakibatkan pencemaran lingkungan.
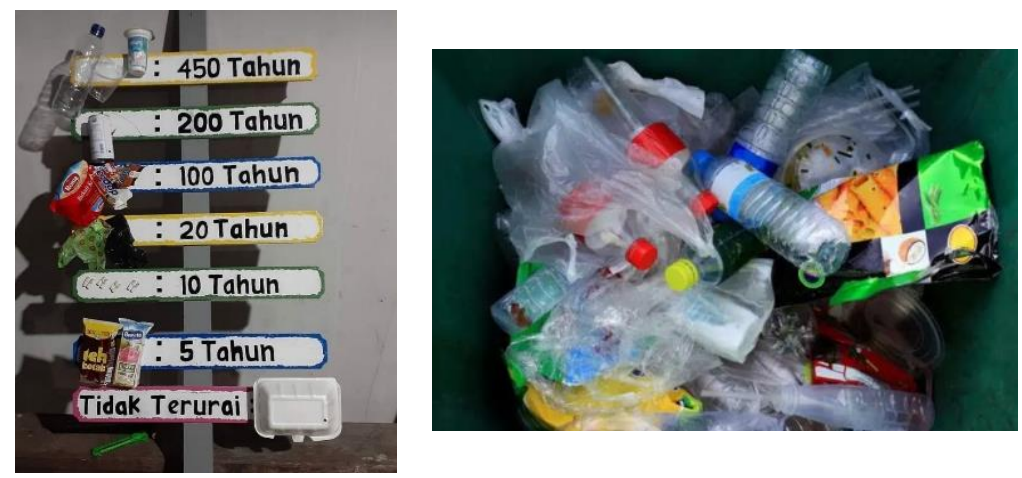

Gambar 1. Jenis sampah dan waktu terurai

Masalah sampah tidak hanya terjadi di kota-kota besar tetapi sudah menjadi masalah di wilayah pedesaan. Masalah sampah juga terlihat di beberapa desa di kecamatan Kwandang. Kecamatan Kwandang secara administratif termasuk dalam wilayah Kabupaten Gorontalo Utara yang memiliki luas wilayah 10,73 \% dari seluruh luas Kabupaten Gorontalo Utara, yang memiliki batas-batas desa masingmasing; sebelah utara berbatasan dengan Laut Sulawesi, dan Kecamatan Pontolo, sebelah timur berbatasan dengan Kecamatan Tomilito, sebelah selatan berbatasan dengan Kabupaten Gorontalo, 
dan sebelah barat berbatasan dengan Kecamatan Anggrek. Di kecamatan Kwandang terdapat tiga desa yang menglami masalah sampah yaitu di Desa Titidu, Desa Moluo dan Desa Cisadane. Di antara beberapa jenis sampah yang banyak di temukan di tiga desa tersebut diantaranya yaitu kantong plastik dari ukuran kecil sampai besar, plastik bungkus detergen, gelas/botol air mineral, plastik kemasan makanan ringan dan lain-lain.

Harapan dari masyarakat tiga desa ini, pemerintah desa dapat memberikan perhatian yang lebih maksimal terhadap masalah sampah. Adapun peran perguruan tinggi yang diharapkan dalam penyelesaian masalah sampah di pedesaan adalah bagaimana pengolahan dan pemanfaatan sampah dengan penerapan Iptek. Secara rinci konteks penerapan iptek yang dimaksud adalah pengolahan sampah plastik menjadi bahan konstruksi.

Berdasarakan latar belakang di atas maka kegiatan proyek di desa kampus merdeka tentang pemanfaatan botol plastik dan sampah plastik sebagai bahan baku konstruksi (ecobrick) di Kecamatan Kwandang Kabupaten Gorontalo Utara sangat tepat untuk dilaksanakan.

\section{METODE PELAKSANAAN}

Tahapan pelaksanaan kegiatan proyek di desa kampus merdeka tentang pemanfaatan botol plastik dan sampah plastik sebagai bahan baku konstruksi (ecobrick) di Kecamatan Kwandang Kabupaten Gorontalo Utara adalah sebagai berikut.

Tahap pertama adalah mensosialisasikan program pengolahan dan pemanfaatan sampah plastik di Desa Titidu, Moluo dan Cisadane. 
Dengan adanya sosialisasi diharapkan adanya pemahaman, dukungan dan kontribusi masyarakat di tiga desa tentang pengolahan dan pemanfaatan sampah plastic.

Tahap kedua adalah tahap pelaksanaan penerapan iptek untuk pengelohan dan pemanfaatan sampah plastic. Pada tahap ini direncanakan terlaksananya pembuatan konstruksi yang menggunakan bata plastik ramah lingkungan (ecobrick) yaitu pada konstruksi tempat sampah dan pembatas desa.

Tahap ketiga adalah evaluasi program, diharapkan adanya keberlanjutan pengelolaan dan pemanfaatan sampah plastik di Desa Titidu, Moluo dan Cisadane sehingga bisa menjadi koreksi kegiatan selanjutnya.

Sedangkan cara pembuatan ecobrick adalah sebagai berikut :

1. Menyiapkan sampah plastik

2. Pilah Penggunaan Plastik

3. Potong Plastik Kaku menjadi Bentuk yang Lebih Kecil

4. Gunakan Tongkat Untuk Memadatkan Plastik

5. Penimbangan Botol

6. Penyusunan Botol Sesuai Pola

7. Pelekatan Eco-Brick

\section{HASIL DAN PEMBAHASAN}

Hasil

Perencanaan program terlebih dahulu didiskusikan dan akan disesuaikan dengan kondisi desa. Pada tanggal 04 September 2020 dilakukan survei lapangan (survei keadaan desa). Hasil observasi yang dilakukan mahasiswa kemudian dilanjutkan dengan rapat perencanaan program kerja yang akan ditawarkan untuk warga 
masyarakat dan karang taruna pada tanggal 07 September 2020 oleh seluruh mahasiswa KKN UNG 2020. Rapat tersebut menghasilkan keputusan bahwa program yang akan dilaksanakan salah satunya adalah pemanfaatn botol plastik bekas dan sampah plastik sebagai bahan konstruksi pembatas dusun, dengan desain dan konstruksi seperti pada Gambar 2.
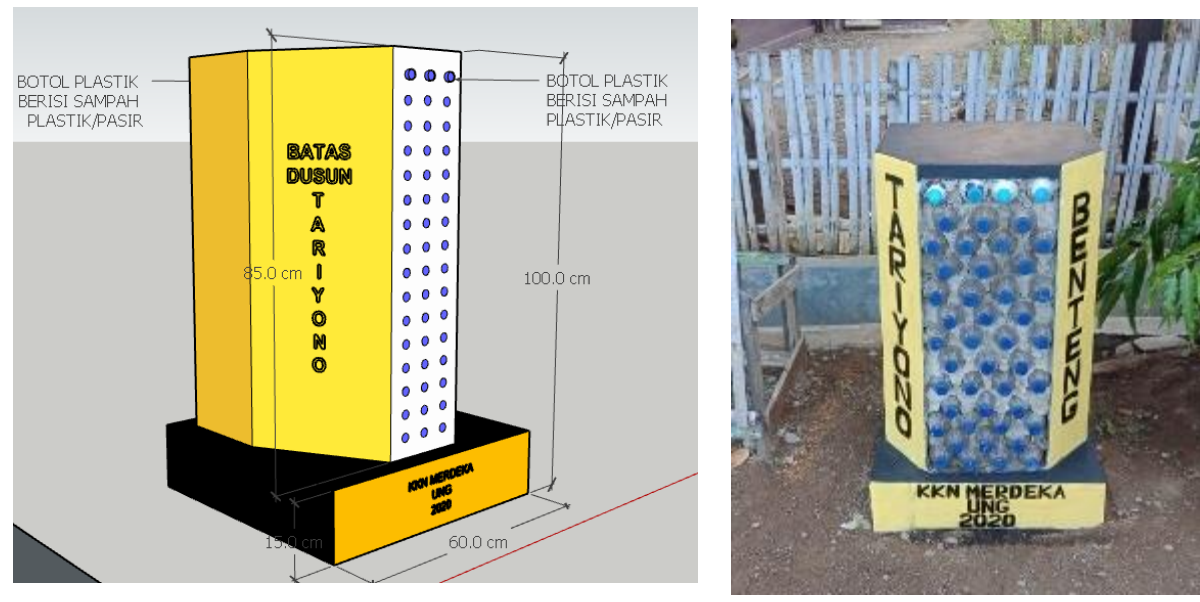

Gambar 2. Gambar desain dan pembuatan konstruksi batas desa dari ecobrick di Desa Cisadane

Hasil observasi dan rapat dengan aparat Desa Titidu maupun Desa Moluo menghasilkan keputusan bahwa salah satu program yang akan dilaksanakan adalah pembangunan Bak Sampah berbahan Ecobrick (bata ramah lingkungan) seperti pada Gambar 3 dan Gambar 4.
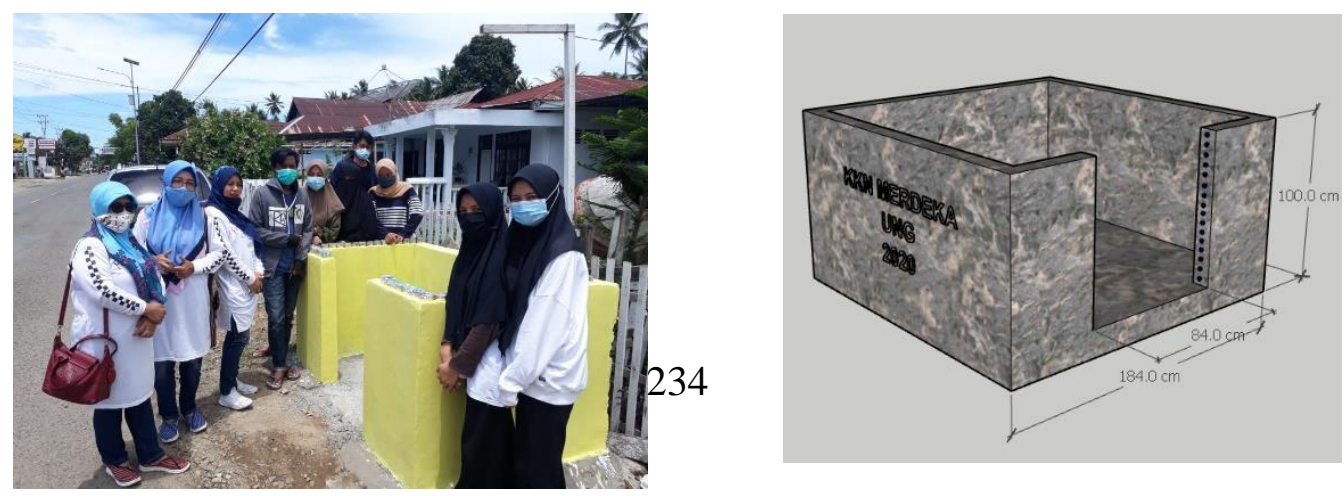
Gambar 3. Gambar desain dan pembuatan konstruksi tempat sampah dari ecobrick di Desa Moluo

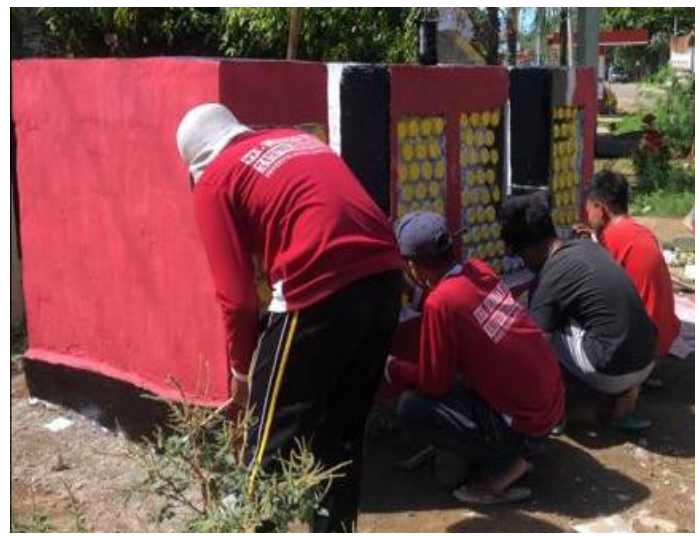

Gambar 4. Pembuatan konstruksi tempat sampah dari ecobrick di Desa Titidu

\section{Pembahasan}

Penggunaan ecobrick dikombinasikan dengan kolom dan balok perangkai. Kolom dan balok perangkai berukuran $20 \times 20 \mathrm{~cm}$. menggunakan tulangan utama minimum yaitu 4 buah dengan diameter $12 \mathrm{~mm}$ dan sengkang diameter $8 \mathrm{~mm}$ dengan jarak $25 \mathrm{~cm}$. Pondasi menggunakan batu kosong dan campuran mortar 1:2. Ecobrick disusun berselang seling sehingga didapat posisi yang stabil. Ecobrick direkatkan dengan mortar campuran 3:1.

Pengawasan program kerja dilakukan oleh berbagai pihak antara lain pihak Lembaga Pengabdian Masyarakat (LPM), Dosen Pembimbing Lapangan (DPL), dan Kepala Desa Cisadane, Titidu dan Moluo. Pengawasan selalu dilakukan seiring dengan kegiatan yang berjalan. Setiap melakukan kegiatan diusahakan selalu ada koordinasi dengan pihak-pihak terkait yang berfungsi sebagai lembaga pengawas KKN. Selain itu mahasiswa KKN selalu berkonsultasi dengan pihak- 
pihak tersebut ketika akan melakukan kegiatan dan apabila ada masalah yang berkaitan dengan kegiatan-kegiatan yang dilakukan di desa.

\section{KESIMPULAN}

Penggunaan batako ataupun batu bata dapat digantikan dengan penggunaan batu bata ramah lingkungan (ecobrick). Ekobrick bisa menjadi alternatif pemanfaatan limbah botol dan sampah plastik yang menjadi salah satu masalah pencemaran lingkungan. Pembuatan ecobrick memakan waktu yang cukup lama, oleh karena itu dapat dilakukan disela-sela waktu luang sehingga suatu saat bila sudah terkumpul dalam jumlah banyak bisa digunakan sekaligus. Apabila waktu yang tersedia cukup singkat isian botol dapat digantikan dengan pasir kering ataupun kerikil. Penggunaan botol dan sampah plastik sebagai batu bata ramah lingkungan tanpa disadari merupakan suatu langkah kecil yang lama kelamaan menimbulkan efek yang sangat besar bagi kelestarian lingkungan.

\section{UCAPAN TERIMA KASIH}

Ucapan terimakasih kepada Rektor Universitas Negeri Gorontalo, Ketua LPM Universitas Negeri Gorontalo, Dosen Pembimbing Lapangan, Camat Kwandang Kabupaten Gorontalo Utara, Kapala Desa, Karang Taruna, Remamuda dan masyarakat Desa Cisadane, Titidu serta Moluo yang telah memberikan arahan, dukungan, motivasi untuk terlaksananya kegiatan KKN Merdeka Belajar UNG 2020. 


\section{REFERENCES}

Anonim. Pedoman Teknis Rumah dan Bangunan Gedung Tahan

Gempa. 2006. Jakarta

Ajeng Galuh Kinantan. 2018. Cara Membuat Ecobrick. https://www. youtube.com/watch?v=5r-Yn-BgZR4\&t=2s

Ani Himawati. 2018.2 Ecobrics.

https://www. youtube.com/watch?v=RQoXtbJTvMs

Nima Waiba. 2017. Plastic Bottles to Toilet, Nepal. https://www.youtube.com/watch?v=AOhgcg7w7bw\&t=15s

Boen T. 1992. Buku Panduan Mengenal Rumah Tahan Gempa 